\title{
KAPITALIZM A KWESTIA MIEJSKA
}

\section{Streszczenie}

W przekształceniach polskich miast $\mathrm{w}$ ostatnim ćwierćwieczu istotną rolę odgrywa renta gruntowa, a jednym z najważniejszych aktorów wytwarzania przestrzeni stali się deweloperzy. W rezultacie następuje prywatyzacja przestrzeni i polaryzacja przestrzenno-społeczna.

Słowa kluczowe: akumulacja, prywatyzacja, polaryzacja

\begin{abstract}
WSTĘP
Przed trzydziestu laty ukazała się moja książka Społeczne wytwarzanie przestrzeni [Jałowiecki 1988], w której starałem się pokazać siły i mechanizmy kształtowania głównie europejskich miast, począwszy od zarania kapitalizmu, datowanego przez niektórych historyków na połowę okresu zwanego średniowieczem. Książka ta była inspirowana La Question Urbaine młodego hiszpańskiego socjologa Manuela Castellsa, który stał się później znanym amerykańskim uczonym. Wersja francuska ukazała się w 1972 roku w lewicowym wydawnictwie Maspero, a przetłumaczona przeze mnie i Jacka Piątkowskiego została wydana po polsku w PWN w 1982 roku [Castells 1982]. Kwestia miejska przełożona na wiele języków stała się najbardziej znanym dziełem marksowskiego nurtu socjologii miasta, który tworzyli, obok Castellsa, Henri Lefebvre, Jean Lojkine i wielu innych, a dzisiaj kontynuują go między innymi David Harvey i Andy Merrifield, którego ostatnia książka Nowa kwestia miejska ukazała się niedawno
\end{abstract}

* Prof. zw. dr hab., Centrum Europejskich Studiów Regionalnych i Lokalnych - EUROREG; e-mail:bm.jalowiecki@gmail.com 
w Wydawnictwie Naukowym PWN [2016]. Nowatorstwo tego nurtu polegało na badaniu miasta $\mathrm{w}$ ścisłym powiązaniu z procesami charakterystycznymi dla kapitalizmu monopolistycznego i pokazaniu szczególnej roli miasta w procesie reprodukcji siły roboczej. W drugim wydaniu Spolecznego wytwarzania przestrzeni [Jałowiecki 2010], które ukazało się przed kilku laty, znalazł się rozdział poświęcony kapitalistycznej transformacji przestrzeni polskich miast. W tym tekście staram się kontynuować poprzednie wątki, ukazując je w kontekście dynamicznie zmieniającej się rzeczywistości.

Miasto stworzyło kapitalizm, zaś kapitalizm podbił miasto. Ta długa historia zaczęła się mniej więcej w XII wieku, kiedy powstawały ośrodki wyspecjalizowane w wymianie handlowo-finansowej na odległość, które określić można jako instytucje handlu zagranicznego. Dzięki nim wiele miast Europy powiązanych było ścisłą ekonomiczną współpracą, na przykład dom handlowy Medyceuszów we Florencji miał swoje przedstawicielstwa w Londynie, Gandawie, Brugii, Lyonie, Awinionie, Mediolanie i w Wenecji. Obroty handlowe między miastami dokonywane były za pomocą listów kredytowych. Miasta zorganizowały więc podstawy nowoczesnego systemu finansowego, który obejmował podatki, kredyty, cło, a nawet pożyczki publiczne. Pierwsza taka pożyczka została rozpisana w Wenecji w 1167 r. (La Casa di San Giorgia). Na dwa wieki przed Tomaszem z Akwinu Alain de Lille powiedział: „To nie Cezar a pieniądz jest dla nas wszystkim, kiedy mówimy pieniądz, to mówimy miasto" [Braudel 1967].

Pierwszy okres można określić mianem kapitalizmu handlowego, chociaż sama nazwa „kapitalizm” jest znacznie późniejsza. Natomiast słowo „kapitalista”, jak pisze Fernand Braudel, pojawiło się wcześniej, bo w połowie XVII wieku, a „o kapitalistach nigdy nie mówi się w przyjazny sposób [...] Marat powiada nawet «W narodach parających się handlem prawie wszyscy kapitaliści i ludzie żyjący z rent bronią tych samych interesów, co poborcy podatkowi, finansiści i spekulanci giełdowi»" [Braudel 1992: 213]. Jeszcze późniejsze jest słowo „kapitalizm”. Prawdopodobnie, jak twierdzi Braudel, pojawiło się w dyskusji Louis Blanca z Claude Bastiatem. „To co będę nazywał kapitalizmem to znaczy przywłaszczenie sobie kapitału przez jednych ze stratą dla drugich" [Braudel 1992: 214]. Do tego pojęcia odwołuje się Pierre-Joseph Prudhon, pisząc: „ziemia jest bastionem kapitalizmu”, i daje taką definicję omawianego zjawiska: „System gospodarczy i społeczny, w którym kapitały będące źródłem dochodu z reguły nie należą do tych, którzy je uruchamiają poprzez własną pracę" [Braudel 1992: 214]. 


\section{ROLA RENTY GRUNTOWEJ W WYTWARZANIU PRZESTRZENI MIAST}

Kapitalizm handlowy przekształca się w przemysłowy, a ten z kolej w finansowy. Narzędziem kapitalistycznego kształtowania miasta staje się renta gruntowa, czyli kapitał uzyskany z wykorzystania przestrzeni. Renta może być statyczna, jak na przykład podatek od nieruchomości pobierany przez władze miasta, lub dynamiczna, czyli stanowiąca różnicę pomiędzy aktualną wartością renty gruntowej danego obszaru wynikającą z istniejącego zagospodarowania i sposobu użytkowania a potencjalną wartością tego terenu, którą można osiągnąć w efekcie rozbudowy i/lub zmiany sposobu użytkowania. Neil Smith nazywa to „luką renty gruntowej" [Smith 1979].

Ten ostatni, dynamiczny rodzaj renty gruntowej, jest charakterystyczny dla finansowego etapu kapitalizmu, inaczej zwanego globalizacją, której skutkiem, a zarazem jedna z cech charakterystycznych, jest metropolizacja. Obecnie na kuli ziemskiej istnieje ponad 400 miast liczących milion i więcej mieszkańców, z czego jedna trzecia w Azji. W 1950 roku wśród 20 największych światowych miast 7 znajdowało się w Europie, obecnie już tylko 3, reszta jest położona w tzw. Trzecim Świecie. Jest to zupełnie nowa sytuacja, ponieważ większość miast, w tym metropolii, kształtuje się w oderwaniu od tradycyjnych modeli i archetypów miasta, które nadal funkcjonują w naszej świadomości. Metropolie rozwijają się względnie niezależnie od podłoża kulturowego danego kraju, według podobnego globalnego schematu i to nie tylko dlatego, że zglobalizowany przemysł budowlany oferuje wszystkim podobne wzory architektoniczne, ale także dlatego, że metropolia wytwarza swoiste struktury społeczne i style życia. Metropolia we współczesnym rozumieniu tego słowa to miasto milionowe, które pełni funkcje kierownicze w gospodarce światowej lub ponadnarodowej i wzorotwórcze w kulturze i obyczajach. Wielkie miasto Nairobi, liczące ponad 3 mln mieszkańców, nie jest metropolią, a jest nią na przykład niemal kilkakrotnie mniejszy Zurich.

Wielkie miasta, a szczególnie metropolie, są areną kapitalistycznej gry o osiągnięcie maksymalnego zysku. Pierwszym takim wielkoskalowym przedsięwzięciem była opisana przez Davida Harveya haussmannowska przebudowa Paryża, operacja nie tylko urbanistyczna, ale przede wszystkim finansowa. W krótkim stosunkowo czasie - bowiem przebudowa trwała około 20 lat (1852-1870) - wytyczono 18 tras komunikacyjnych, przekształcono 60\% budynków, wyburzono większą część średniowiecznego miasta. Koszty wynosiły ok. 50-60 mln fr. rocznie, co było w owym czasie kwotą ogromną. Realizacja przedsięwzięcia była 
możliwa dzięki nadwyżkom kapitałowym zgromadzonym po wojnach napoleońskich oraz napływowi do miasta siły roboczej. Dynamiczna renta gruntowa w połączeniu z rentą różniczkową umożliwiła uzyskanie ogromnych zysków, np. teren usytuowany wzdłuż bulwaru Sewastopol w 1850 roku kosztował $25 \mathrm{fr}$. za metr kwadratowy, a w siedem lat później już 100 fr. Po wystawie z 1867 roku wartość ziemi na niektórych obszarach po lewej stronie Sekwany wzrosła dziesięciokrotnie w ciagu dwóch lat. Cena gruntów była bardzo zróżnicowana, np. w okolicach Hal płacono 1000 fr. za m kw., a już na niedalekiej ulicy Saint Denis - 600 fr, we wschodnich robotniczych dzielnicach zaś 150-250 fr. Ogółem wartość rynku nieruchomości w latach 1852-1870 wzrosła z 2,5 do 6 mld fr., w tym 1,5 mld to wzrost cen nieruchomości istniejących przed przebudową [Harvey 2012a: 217-218].

Podobne operacje o różnej skali można obserwować współcześnie w wielu miastach i metropoliach świata. „Neohaussmannizacja - pisze Andy Merrifield - wyznacza nowy rys w starej opowieści o miejskiej transformacji, o zasadzie «dziel i rządź» materializowanej środkami zmiany miejskiej, o przerabianiu i zwiększaniu skali fizycznego środowiska zurbanizowanego mającego na celu zmianę krajobrazu społecznego i politycznego" [Merrifield 2016: 3]. Liczne prace na temat renowacji, rewitalizacji, modernizacji, gentryfikacji, grodzenia pokazują ekonomiczne i społeczne skutki tych procesów. Widoczne są one także w polskich miastach, a szczególnie w Warszawie. Z analizy cen przeprowadzonej przez portal nieruchomości domy.pl wynika, że ceny działek budowlanych w Warszawie należą do najwyższych w Polsce. W stolicy średnia stawka za metr kwadratowy wynosi aż 1117 zł, czyli blisko dwa razy więcej niż w zajmującym drugie miejsce pod względem wysokości cen Wrocławiu (604 zł za m kw.). Stolicy Dolnego Śląska tylko nieznacznie ustępuje Kraków, w którym średnia stawka za metr kwadratowy wynosi 598 zł. Trzy razy tańsze niż w Warszawie są działki budowlane w Szczecinie (373 zł), Białymstoku (348 zł) i Łodzi (344 zł), a prawie cztery razy mniej trzeba zapłacić za metr kwadratowy działki pod budowę domu w Katowicach $(307 \mathrm{zl})^{1}$. Przykładowo najdroższa działka w Warszawie przy ul. Nowy Świat kosztowała 12 tys. zł za m kw. Przy nieodległej ul. Mokotowskiej -4 tys. zł, na peryferyjnym Bemowie $-1,2$ tys. zł, a w jeszcze bardziej odległej Białołęce - ok. 0,4 tys. zł za m kw.

Wysokie ceny działek skłaniają inwestorów do maksymalizacji wykorzystania terenu, zgodnie z ekologiczną hipotezą Jamesa Quinna [Jałowiecki, Kostrubiec

1 http://biznes.interia.pl/nieruchomosci/news/ceny-dzialek-budowlanych-w-polsce, 1828732,4206 . 
1970]. I tak na przykład w Warszawie na obszarze Śródmieścia w fazie budowy lub planowania znajduje się 25 wieżowców o wysokości od 95 do 200 metrów. Cześć tych oddanych do użytku i konstruowanych budynków wznoszonych jest na miejscu burzonych, często nowych, obiektów, jak np. hotel Mercure, dom towarowy obok hotelu Holiday Inn; oddany do użytku w 1997 roku wieżowiec Ilmetu liczący $93 \mathrm{~m}$ ma być zastąpiony przez nowy o wysokości $188 \mathrm{~m}$. Pod kilof idą jednak częściej starsze budowle, jak np. unikatowy konstrukcyjnie modernistyczny Supersam, Teatr Żydowski, Rotunda PKO, budynek Universalu, dawny CDT (Smyk), kino Moskwa, dom handlowy Sezam, nie licząc dawnych budynków fabrycznych i ocalałych z wojny kamienic.

Koniunktura na warszawskim rynku lokali biurowych trwa, a zatem inwestycje przynoszą stosunkowo szybki zwrot kapitału i znaczne zyski. W nowoczesnych budynkach biurowych w ścisłym centrum Warszawy ceny wynajmu powierzchni przeciętnie kształtują się na poziomie 20-25 EUR za m kw. W starszych budynkach ceny wynajmu zaczynają się już od 17 EUR, a w najbardziej luksusowych budynkach wynoszą nawet 65 EUR za m kw. Drugim największym ośrodkiem jest Służewiec przemysłowy, powszechnie nazywany „Mordorem”. Tutaj można liczyć na czynsze już od 10 EUR za m kw².

Miejsca pracy biurowej zastępują miejsca pracy w przemyśle, w Warszawie i w innych potencjalnych metropoliach obserwować można intensywny proces deindustrializacji. W stolicy zatrudnienie w przemyśle, w porównaniu do 1971 roku, zmalało o 18 punktów procentowych i wynosiło w 2004 roku 14,7\%. W Łodzi spadek był jeszcze większy i wyniósł 27 punktów. Zmiany te oznaczają przekształcenie struktury społecznej miast, zmiany potoków ruchu i miejskiej czasoprzestrzeni.

Sytuacja na rynku nieruchomości w znacznym stopniu determinuje sposób wytwarzania przestrzeni i ma także poważne skutki społeczne. Wyburzanie istniejących obiektów w dobrym stanie technicznym i spełniających kryteria użytkowe jest marnotrawstwem zasobów, podobnie jak wyrzucanie do śmieci żywności zdatnej do spożycia czy też wymiana niemodnych sprzętów gospodarstwa domowego na nowe modele. Obok skutków ekonomicznych nowe obiekty wznoszone z reguły na dostępnych przypadkowych działkach powodują zmiany funkcjonowania dużych obszarów miasta oraz zmiany jego krajobrazu. Duże zgrupowanie miejsc pracy biurowej powoduje trudności transportowe oraz wypłukiwanie $\mathrm{z}$ centrów miast wielu tradycyjnych funkcji usługowych, handlowych, mieszkaniowych i rozrywkowych.

2 http://prnews.pl/wiadomosci/ceny-wynajmu-biur-w-warszawie-luty-2016-r-3478841.html. 


\section{KREDYT A SEGREGACJA SPOLECZNO-PRZESTRZENNA}

Wysoki koszt działek indukuje ceny mieszkań. Lokal o powierzchni 38$-60 \mathrm{~m}$ kw. kosztował w Warszawie 7737 zł za m kw. O ponad $1000 \mathrm{zł} / \mathrm{m}^{2}$. tańsze były podobne mieszkania w Krakowie, a o 1700 zł - w Gdańsku. Znacznie wyższe ceny, o ok. 600 zł, były na rynku wtórnym ${ }^{3}$. Brak mieszkań na wynajem o umiarkowanym czynszu powoduje konieczność kupowania mieszkań na własność i zaciagania długoletniego kredytu hipotecznego, który jest na ogół głównym źródłem dochodów banków. W pewnych warunkach kredyty hipoteczne moga przyczynić się do gospodarczego kryzysu, jak to było w 2008 roku w Stanach Zjednoczonych, gdzie masowo udzielano pożyczek osobom niemającym zdolności kredytowej. W rezultacie niespłacania należności nastapił krach w sektorze bankowym, lokatorzy zostali eksmitowani z mieszkań, tracąc własny wkład, a puste domy rozwalano buldożerami.

Inny rodzaj kryzysu hipotecznego pojawił się w Polsce, gdy banki namawiały klientów do zaciagania pożyczek we frankach szwajcarskich, których oprocentowanie było niższe niż złotego, nie informując o możliwych skutkach różnicy kursowej, chociaż kredyt był spłacany w złotówkach. W rezultacie skokowego wzrostu kursu franka raty kredytu silnie rosły, doprowadzając do sytuacji, w której w wielu przypadkach kwota mimo wcześniejszego spłacania rat rosła, a dług przekraczał wartość mieszkania. Praktyka ta znalazła polityczne odbicie w obietnicach wyborczych rozwiązania problemów tzw. frankowiczów, które jednak nie zostały dotrzymane. Kredyty frankowe przyczyniły się wprawdzie do wzrostu liczby budowanych mieszkań, ale wywołały także napięcia społeczne. Problem ten badał Mateusz Halawa, wskazując na dwa aspekty kredytu hipotecznego, który może polegać „na wyssaniu wartości z już istniejącej tkanki miejskiej”, kiedy pożyczamy pieniądze pod zastaw własnej nieruchomości. $Z$ drugiej strony wzięcie kredytu hipotecznego może służyć budowaniu i kupowaniu gotowych mieszkań. Autor wskazuje także na inne skutki, stwierdzając, że proces suburbanizacji jest skorelowany z akcją kredytową. Kredyt generuje także nierówności społeczne, ludzie dzielą się bowiem na tych, którzy mają zdolność kredytową i na takich, którzy jej nie mają. Dostęp do mieszkania jest ważną cechą społecznego zróżnicowania. Mamy na przykład dwie rodziny o zarobkach 5000 zł, jedni odziedziczyli mieszkanie po rodzicach kupione od miasta za grosze, drudzy, przyjezdni, muszą je wynajmować. Mieszkanie pierwszych kosztuje 500 zł, a drugich $2500 \mathrm{zl}$ [Halawa 2015].

\footnotetext{
3 http://www.bankier.pl/wiadomosc/Raport-z-rynku-mieszkan-listopad-2016-7483938.html.
} 
Funkcjonowanie rynku mieszkaniowego w sytuacji stałego niedoboru mieszkań o pożądanym standardzie uruchamia mechanizm ruchu ludności i jej segregację w przestrzeni, w rezultacie łączenie się ludności w „klasy mieszkaniowe” (housing class). Autor tej koncepcji, John Rex, wyróżnia w wielkich miastach kilka klas mieszkaniowych: pełnoprawnych właścicieli mieszkań w najlepszych dzielnicach, właścicieli podobnych mieszkań z niespłaconą hipoteką, właścicieli mieszkań obciążonych hipotecznie w gorszych dzielnicach, najemców prywatnie wynajmujących lokale oraz lokatorów mieszkań komunalnych. Osoby należące do wyższych klas mieszkaniowych, tzw. białe kołnierzyki (white collars), starały się opuścić centralne dzielnice, przenosząc się na peryferie, zaś w tych ostatnich wynajmowane mieszkania, przeważnie komunalne, zajmowała klasa robotnicza (blue collars). Jak twierdzi Rex, dostęp do mieszkań komunalnych i możliwość uzyskania kredytu stanowią główne przyczyny konfliktów społecznych wokół mieszkalnictwa. W najgorszej sytuacji znajdują się osoby pozbawione zarówno dostępu do kredytów, jak i do mieszkań komunalnych (przeważnie imigranci). Skazane są one na wynajem prywatny w zdegradowanych i przeludnionych domach, w tzw. strefach przejściowych, na obrzeżach śródmiejskich dzielnic handlowo-rozrywkowych [Giddens 1988: 117] lub na peryferiach. To nie „kultura" ani religia, a kapitalistyczna eksploatacja przestrzeni miejskiej powoduje powstawanie emigranckich gett w miastach zachodniej Europy.

Polityka mieszkaniowa polskiego państwa i miast po 1990 roku polega na urynkowieniu w zasadzie nietowarowego dobra - ponieważ każdy człowiek posiada prawo do dachu nad głową - jakim jest mieszkanie $Z$ jednej strony nastąpiła wyprzedaż istniejących lokali komunalnych i spółdzielczych po umownych nieodpowiadających wartości cenach, a z drugiej rozwój deweloperskiego budownictwa komercyjnego na sprzedaż. W Polsce, w przeciwieństwie do Niemiec czy Francji, praktycznie nie istnieje park społecznych mieszkań na wynajem o czynszach umiarkowanych. Kolejne rządy subsydiowały w pewnym stopniu kredyty mieszkaniowe, co zwiększało, co prawda, liczbę osób mających zdolność kredytową, ale równocześnie napędzało klientów bankom, zwiększając ich zyski.

Kolejnym przykładem „łupieżczych praktyk miejskich” [Harvey 2012b] są działania polskich właścicieli kamienic, którzy odzyskali je w ramach tzw. dzikiej reprywatyzacji wraz z lokatorami nazywanymi w żargonie reprywatyzatorów „wkładką mięsną". Pierwszym krokiem było zwykle drastyczne podniesienie czynszu, którego nie byli w stanie płacić mniej zamożni lokatorzy, w drugim etapie pojawiali się „czyściciele kamienic”, którzy odcinali media pod pozorem remontu, demolowali klatkę schodową, rozpleniali insekty. Pomysłowość w sto- 
sowaniu szykan mających zmusić dotychczasowych mieszkańców do zwolnienia lokalu nie ma granic. W wielu przypadkach lokatorzy po opuszczeniu mieszkania zostają z pokaźnym długiem za „bezumowne użytkowanie mieszkania”. Polskie prawo, a także sądy sprzyjają tym łupieżczym praktykom, uznając wątpliwe tytuły własności i handel nimi. Podstawowym błędem umożliwiającym te „legalne” działania jest przekonanie wszystkich rządów o nienaruszalności „świętego prawa własności" i rzekomej konieczności wyrównania krzywd doznanych przez właścicieli, i ich często dalekich spadkobierców, od niemieckiego okupanta oraz „komunistycznego reżimu”. W istocie jednak reprywatyzacja po polsku jest przykładem kapitalistycznej akumulacji, której genezy należy szukać w rugach chłopskich w osiemnastowiecznej Anglii.

O powszechności łupieżczych praktyk miejskich świadczą liczne przykłady z innych krajów, m.in. z Francji [Castells 1982] i Stanów Zjednoczonych, które opisuje David Harvey: „Bardzo liczne są łupieżcze praktyki uderzające w biednych, bezbronnych i już dyskryminowanych. Każdy mały niezapłacony rachunek (np. abonament albo opłata za wodę) może przerodzić się w zastaw nieruchomości o czym właściciel może nie zostać poinformowany. Aż do momentu kiedy jakiś prawnik wykupi ów zastaw i nałoży na niego takie koszty, że początkowo niezapłacony rachunek w wysokości, powiedzmy 100 dolarów wymaga np. 2500 dolarów spłaty. Dla większości biednych ludzi oznacza to utratę nieruchomości" [Harvey 2012b: 89].

\section{DEWELOPER JAKO GLÓWNY AKTOR WYTWARZANIA PRZESTRZENI POLSKICH MIAST}

Polska zajmuje jedno z ostatnich miejsc w liczbie mieszkań na 1000 mieszkańców (335); dla porównania w krajach o zbliżonym poziomie rozwoju liczby te wynoszą: w Grecji - 505, w Portugalii - 495, a nawet w Rumunii - 381. Według szacunków GUS w stosunku do liczby gospodarstw domowych brakuje w Polsce 1,5 mln mieszkań. Liczba oddanych do użytku lokali wahała się znacznie w okresie 1991-2015. W 1991 roku wybudowano ok. 137 tys. mieszkań, zapaść nastapiła w 1996 roku, kiedy do użytku oddano ok. 62 tys. Stopniowo liczba budowanych lokali rosła, osiagając szczyt w 2003 roku (162 tys. $)^{4}$. Produkcja budowlana w okresie po transformacji ustrojowej była znacznie mniejsza niż w Polsce Ludowej, bowiem w latach 1964-1989 budowano nie mniej niż 150 tys. mieszkań

4 http://stat.gov.pl/obszary-tematyczne/przemysl-budownictwo-srodki-trwale/budownictwo/ budownictwo-mieszkaniowe-tablice-przegladowe-od-1991-roku,6,4.html 
rocznie, a w 1978 roku wybudowano aż 283 tys. lokali mieszkalnych. Obecnie wśród inwestorów - jak podaje Roman Nowicki - ponad połowę (54\%) stanowią osoby indywidualne, 34\% - deweloperzy, zaś 13\% - inni (spółdzielnie i gminy), przy czym w 6 największych aglomeracjach miejskich skupione jest 54\% budownictwa deweloperskiego ${ }^{5}$. Działalność deweloperska należy do najbardziej rentownych, a jej marża stale rośnie. O ile jeszcze niedawno wynosiła ona $18 \%$, to obecnie sięga 35\%. O opłacalności tej branży świadczy fakt, że angażują się w nią przedsiębiorcy z różnych dziedzin.

Ta forma budownictwa mieszkaniowego ma charakter patologiczny, gdyż w wielu przypadkach opiera się na wykorzystywaniu słabości przedsiębiorstw działających na tym rynku, a trzeba zaznaczyć, że obok dużych, często zagranicznych firm, istnieje też na nim wiele małych podmiotów. Z drugiej strony na rynku pojawiają się firmy krzaki wyłudzające pieniądze od potencjalnych nabywców. W obu przypadkach może oznaczać to utratę pieniędzy. Kolejnym przykładem patologii są praktyki firm deweloperskich, które prywatyzując zysk ze sprzedaży samych mieszkań, uspołeczniają koszty infrastruktury technicznej i społecznej, przerzucając je na samorządy, a więc na wszystkich mieszkańców miasta.

Tak zwane Miasteczko Wilanów w Warszawie zostało wybudowane na terenie kupionym od Szkoły Głównej Gospodarstwa Wiejskiego, czyli instytucji państwowej. Po wzniesieniu bloków mieszkalnych okazało się, że ich mieszkańcy nie mają na miejscu ani szkoły, ani innych usług, a nawet ulic. Do ich wytyczenia zobowiązany jest zarząd miasta, który musi wykupić od dewelopera potrzebny na to teren. Prokom i powiązane z nim spółki chciały od miasta ok. $80 \mathrm{mln}$ zł za grunty pod główne drogi w osiedlu. W końcu deweloper użyczył gruntu, żeby przyspieszyć realizację inwestycji. Polnord, jako nowy właściciel ziemi, nie zrezygnował jednak wcale z ubiegania się o odszkodowanie od miasta, a kwota wzrosła do $115 \mathrm{mln}$. Roszczenie to firma sprzedała bankowi. „Jesteśmy na giełdzie i nie możemy sprzedawać majątku za półdarmo, gdyż to byłoby działanie na szkodę spółki" - twierdzi przedstawiciel firmy ${ }^{6}$. Polityka miejska działa w interesie dewelopera i wyraźnie go faworyzuje. Przykład ten pokazuje, że niezależnie od różnych form ustrojowo-prawnych jeden podmiot społeczny (państwowe SGGW) sprzedaje teren prywatnemu przedsiębiorcy, którego część następnie odkupuje od niego znacznie drożej drugi podmiot społeczny (samorząd), czyli w rezultacie podatnik.

5 https://www.google.pl/\#q=liczba+budowanych+mieszka\%C5\%84+w+europie

${ }_{6}$ http://www.rp.pl/artykul/89442-Miasteczko-Wilanow-prawie-jak-wioska.html 
Jednym ze źródeł napięć i konfliktów w praktykach miejskich są miejscowe plany zagospodarowania przestrzennego, które stają się polem gry prowadzonej przez różnych aktorów mających sprzeczne interesy, rozstrzygane nie w wyniku fachowego arbitrażu, ale przez głosowanie zwykle mało kompetentnych radnych. Oto jeden z przykładów takiej gry interesów następujących aktorów: dewelopera zamierzającego budować osiedle grodzone, zamykające dojście do sąsiedniego lasu, firmy planującej rozbudowę hipermarketu, radnych oraz mieszkańców tej części dzielnicy. Projekt planu przewidywał między innymi zachowanie terenów zielonych na obrzeżu lasu, zgodę na niewielką rozbudowę hipermarketu i przeniesienie pętli autobusowej w pobliżu terenu należącego do dewelopera. W toku dyskusji uformowały się dwa wyraźne obozy, z jednej strony deweloper i cześć popierających go radnych, z drugiej pozostali reprezentanci ludu i sami mieszkańcy. Pierwszy obóz dążył do storpedowania uchwalenia planu pod pretekstem zgody na rozbudowę Tesco, zaś drugi zmierzał do jego szybkiego uchwalenia w celu zablokowania inwestycji dewelopera. W atmosferze pomówień i oskarżeń o korupcję rada dzielnicy negatywnie zaopiniowała plan, który znalazł uznanie dopiero w radzie miasta, która go ostatecznie uchwaliła ${ }^{7}$.

Świat deweloperów to nie tylko ,arogancja” wieżowców, to przede wszystkim sposób wytwarzania przestrzeni najmniejszym kosztem i z największym zyskiem. Warszawa jest zabudowywana chaotycznie, ponieważ domy wznosi się nie tam, gdzie byłoby to racjonalne, lecz tam, gdzie można tanio nabyć działkę i drogo sprzedać mieszkania; buduje się wysoko i ciasno, toteż nie ma miejsca na zieleń i usługi. Nikt nie troszczy się o to, że z tych blokowisk, często o niskim standardzie, nie można swobodnie dojechać do pracy i do centrum.

Deweloperzy działający na konkurencyjnym rynku stosują różne marketingowe techniki mające przyciagnąć klientów. Oddziałują na wyobraźnię, stosując nieraz oszukańczą reklamę. Nieuświadomione tęsknoty ma zaspokajać sfera werbalna; chodzi nie tylko o sprzedanie mieszkań, lecz także marzeń, kontaktu z wielkim światem. Jest to swoisty paradoks w zestawieniu z zamkniętymi osiedlami, otoczonymi murami lub płotami. Wola Prestige, Kazimierzowska Residence, Platinum Towers, Electra Resort, Sand City Tower to nazwy mające przenieść mieszkańców w inny świat; jedna z firm, nazywając osiedle Heaven, czyli niebo, pragnie nawet przenieść przyszłych lokatorów w zaświaty. Do filozofii dalekowschodniej nawiązuje zespół mieszkaniowy w Ożarowie Mazowieckim,

7 Informacje uzyskane z niepublikowanego opracowania Karoliny Mioduszewskiej wykonanego w Akademii Rozwoju Regionalnego prowadzonej przez Centrum Europejskich Studiów Regionalnych i Lokalnych. 
używając nazwy Zen Garden. Z kolei na Bemowie powstaje osiedle Villa L'Azur, na Polach Wilanowskich - La Lumiére (Światło), a najnowszą planowaną inwestycję przy ul. Włodarzewskiej nazwano Mont Blanc. Niekiedy łączenie słowa polskiego $\mathrm{z}$ angielskim czy francuskim, mające $\mathrm{w}$ zamierzeniu autorów wiązać rzeczywistość z marzeniem, daje efekt komiczny (jak np. Pludy Village). Marina na warszawskim Mokotowie nie ma oczywiście nic wspólnego z morzem i należy także do kategorii nazw absurdalnych. Obok powyższych zachęt wyrażanych w nazwach dodatkowymi atutami mają być: zieleń, cisza, dobra komunikacja, lokalizacja blisko centrum itp., a przede wszystkim bezpieczeństwo, ponieważ osiedle jest grodzone i strzeżone. Fakt ten często przekonuje nabywców do podjęcia decyzji o kupnie mieszkania w danym miejscu.

\section{PRYWATYZACJA PRZESTRZENI}

Ryzyko w ponowoczesnym świecie staje się problemem codziennego życia. Związane jest ono ściśle z globalizacją w wielu jej wymiarach znajdujących swoje odbicie w codzienności miliardów ludzi, którzy stykając się nie tylko z globalnymi, ale także z lokalnymi zagrożeniami, żyją w ciagłym poczuciu lęku. To poczucie lęku wywołuje pragnienie nowej utopii, którą projektuje na przykład brytyjski architekt George Hazeldon. Tak pisze o tym Zygmunt Bauman: „marzy (on) o mieście innym niż wszystkie, wolnym od widoku złowrogich obcych sylwetek wypełzających chyłkiem z mrocznych zaułków, podejrzanych uliczek i niebezpiecznych dzielnic" [Bauman 2006: 141]. Byłoby to zatem miasto zamieszkałe przez ,samych swoich”, ludzi sytych i bogatych.

Ponieważ trudno jest ograniczyć ryzyko globalizacji, budując takie miasta, można na razie próbować zabezpieczyć się w skali lokalnej. Próbą takiego zabezpieczenia jest schronienie się w osiedlach „za bramą”, dające złudzenie bezpieczeństwa i ochrony przed wrogim otoczeniem. Powstają zatem nowe miejskie społeczności, których głównym, jeżeli nie jedynym, spoiwem jest strach.

„Mieszkańcy osiedli zamkniętych wykorzystują mury, bramy i ochronę aby trzymać z dala od swoich domostw i osiedli całą gamę postrzeganych niebezpieczeństw. Nie dostrzegają już swojego codziennego społecznego otoczenia jako wspólnoty zdyscyplinowanych obywateli, którzy podzielają ich wartości i normy. Odległość fizyczna między nimi a «innymi» jest tak niewielka, że kontakt z nimi wywołuje strach, powodując budowę prywatnych, wyłączających osiedli, które pozwalają trzymać za pomocą murów i ochroniarzy «obcych» na odległość. Mury zaś uwidaczniają społeczną kontrolę i inność klasy znajdującej się w ich obrębie" [Low 2003: 156]. „Dla wielu bogatych Amerykanów mieszkanie w osiedlu oto- 
czonym murami stanowi sposób na korzystanie ze swojej pozycji ekonomicznej oraz pozbawienie innych ludzi możliwości dzielenia z nimi płynących z niej przywilejów” [Rifkin 2001]. Fenomen „osiedli za bramą" najwcześniej rozwinął się w Stanach Zjednoczonych i w Ameryce Łacińskiej, ale wkrótce dotarł do Europy, w tym także do Polski, gdzie przybrał, szczególnie w Warszawie, spektakularne rozmiary.

W Europie Zachodniej zjawisko to jest znacznie mniej rozwinięte. Na przykład we Francji w 2002 r. według szacunkowych danych istniały 183 strzeżone osiedla, w tym jedynie 72 grodzone, pozostałe chronione były kamerami wideo, domofonami, a w 14 przypadkach zatrudniano dozorcę [Billard, Chevalier, Madoré 2005]. Również w Niemczech zjawisko nie jest jak na razie rozpowszechnione; np. w Berlinie na granicy z Poczdamem istnieje tylko jedno takie osiedle - Arkadien. Na tym tle Warszawa, w której liczba „osiedli za bramą” przekracza 200, nie tylko osiaga, ale i przewyższa amerykańskie statystyki. Zjawisko to budzi żywe emocje zarówno wśród zwolenników tej formy mieszkalnictwa, jak i jej przeciwników, a także zainteresowanie socjologów i dziennikarzy. Pojawia się więc na ten temat coraz więcej badań oraz artykułów w prasie, dostarczających aktualnej wiedzy. Oto kilka przykładów zaczerpniętych z „Gazety Wyborczej”.

Ulica Zbyszka Cybulskiego była kiedyś małą alejką na terenie należącym do Wytwórni Filmów Fabularnych i Dokumentalnych przy Chełmskiej. Można nią było przejść wzdłuż ogrodzenia wytwórni i dojść na łąkę. Gdy na końcu drogi wybudowano luksusowy apartamentowiec „Villa Monaco” z bardzo drogimi mieszkaniami, ul. Cybulskiego zamknięto. O tym, kto może tu wjechać, decyduje ochroniarz. - Mieszkańców już kojarzę z widzenia i od razu otwieram. Obcych pytam, do kogo jadą, i zapisuję numer rejestracyjny. Jeśli ktoś chce wjechać ot tak sobie, nie wpuszczam. Tu mieszkają bogaci ludzie i nie życzą sobie, żeby byle kto szwendał im się przed oknami - mówi. Wkrótce zamknięta zostanie też ul. Kaszubska. - My ten teren dzierżawimy wieczyście i możemy zagospodarować w taki sposób, jaki uważamy za stosowny mówi Zuzanna Kołodziej z firmy Eko Classic, która postawi przy Kaszubskiej apartamentowiec. Obcy nie wejdzie na żadną z ulic budowanego właśnie osiedla Marina Mokotów obejmującego 32 ha. Będzie to zamknięta dzielnica na blisko 5 tys. mieszkańców. Stołeczne władze sprzedały deweloperowi teren, nie wytyczając jednak w środku sieci publicznych dróg. Deweloper sam je wyznaczył i wystąpił do rady miasta o nadanie nazw. Ulice pojawią się na planie miasta, ale nikt poza mieszkańcami nie będzie miał prawa nimi przejść [Zieliński 2005].

Ta obsesja bezpieczeństwa pojawia się jako główny motyw wyboru mieszkania w „osiedlach za bramą”, przybierając nieraz formę swoistej paranoi. Za poczuciem zagrożenia kryją się jednak także inne motywy, które respondenci niechętnie ujawniają. Jest to pogarda dla ludzi biedniejszych od nas, którym się nie powiodło, których nie stać na luksusowe mieszkanie, prywatne szkoły, zagraniczne wyjaz- 
dy. Są to postawy charakterystyczne dla dorobkiewiczów i nuworyszy, którym mieszkanie w zamkniętym osiedlu daje poczucie wyższości i zapewnia prestiż.

Prywatyzacja przestrzeni odbywa się także za sprawą wielkich korporacji, które aranżując dla swoich potrzeb duże fragmenty miasta, oddają pod określonymi warunkami niektóre fragmenty tych realizacji do użytku publicznego. „Liczne już opracowania - pisze Maria Gravari-Barbas - wyraźnie pokazują wzrastającą prywatyzację przestrzeni publicznych. Postnowoczesne miasto zrywa z modelem istniejącym od czasów Hausmanna i miasta postliberalnego zgodnie z którym superstruktura była prywatna, podczas gdy przestrzenie zewnętrzne: ulice, place, infrastruktura i urządzenia zbiorowe stanowiły domenę publiczna. Obecnie obserwuje się szybki rozwój przestrzeni prywatnych «oferowanych» do użytku publicznego. Jednakże przeciwnie do tego co można by oczekiwać to zjawisko przestrzeni publiczno-prywatnej nie powoduje rozszerzenia publicznie dostępnych obszarów miasta, ale przeciwnie komercjalizację prawdziwych przestrzeni publicznych" [Gravari-Barbas 2001].

Przestrzenią prywatną, oddaną jedynie do publicznego użytku, są centra handlowe, które powstały w rezultacie wcześniejszych procesów: rozbicia zwartości miast, rozbudowy obszarów poza dotychczasowym terenem zainwestowania miejskiego, a przede wszystkim suburbanizacji. Powstanie centrów handlowych przekształca strukturę przestrzenno-społeczną miasta, zmieniając kierunki ciążenia i potoki ruchu, które zmierzają w różnych kierunkach, omijając centrum miasta. Jego przestrzeń staje się coraz bardziej zdecentralizowana i zdehierachizowana. Centra handlowe przyczyniają się także do wzrostu segregacji społecznej, upośledzając osoby starsze i niezamożne, które nie mogą korzystać z samochodu. Centra zmieniają ponadto geografię handlu. Liczne wcześniej w centrach miast placówki handlowe i usługowe nie wytrzymują konkurencji; najwcześniej upadają rzemieślnicy, następnie sklepy spożywcze, a wreszcie placówki oferujące standardowe produkty: odzież, artykuły gospodarstwa domowego itd. Zwolnione lokale zajmują oddziały banków, agencje turystyczne, punkty sprzedaży telefonów komórkowych oraz sklepy oferujące markową odzież i kosmetyki. Jedynie apteki utrzymują jak na razie swoje centralne lokalizacje.

Galerie handlowe poddane są ścisłej kontroli, zarówno ze strony administratorów obiektu, co dotyczy np. zakazu fotografowania, jak i klientów. Polega ona - jak pisze Grzegorz Makowski - na tym, że „,chodzą odpowiednio ubrani [...] wykorzystują przestrzeń mokotowskiego centrum zgodnie z jego przeznaczeniem [...] dlatego dziwią się, jeżeli dowiedzą się, że ktoś przychodzi do Galerii tylko po to, żeby na przykład poczytać Biblie albo jakąś inną książkę. Szokuje ich fakt, 
że dzieci z pobliskich osiedli spędzają tutaj całe dnie na zabawach w chowanego [...] i z obrzydzeniem patrzą na grupę punków..." [Makowski 2003: 127]. Tak więc zachowania, które byłyby naturalne w tradycyjnej przestrzeni publicznej, na ulicy czy w parku, w świątyni konsumpcji są niedozwolone.

\section{ZAKOŃCZENIE}

Miasto stworzyło kapitalizm, zaś kapitalizm podbił miasto. Henri Lefebvre w swojej wypowiedzi na Kongresie Międzynarodowego Towarzystwa Socjologicznego w 1972 roku w Caracas mówił: „Urbanizacji społeczeństwa towarzyszy ogólna degradacja życia miejskiego, rozbicie centrów miejskich pozbawionych życia społecznego oraz selektywne rozproszenie ludzi w przestrzeni. Istnieje prawdziwa sprzeczność, którą nazywam sprzecznością przestrzeni. $Z$ jednej strony, klasa panująca i Państwo umacniają miasto jako centrum potęgi i decyzji politycznych, a z drugiej, panowanie tej klasy i jej Państwa rozbija miasto" [Lefebvre 1972: 258-259]. W Polsce prywatyzacja przestrzeni dokonuje się bez żadnej kontroli, miasta nie mają planów zagospodarowania przestrzennego, tak więc decyzje lokalizacyjne wydaje się uznaniowo. Sytuacja taka jest wyjątkowa w europejskich krajach zawansowanego kapitalizmu, gdzie rynek nie decyduje swobodnie o zagospodarowaniu przestrzeni, typowa jest natomiast dla krajów peryferyjnego kapitalizmu.

\section{BIBLIOGRAFIA}

Bauman Zygmunt. 2006. Płynna nowoczesność. Kraków: Wydawnictwo Literackie.

Gerard Billard, Jacques Chevalier, François Madoré. 2005. Ville fermée, ville surveillée. Rennes: Presses Universitaires de Rennes.

Braudel Fernand. 1967. Civilisation matérielle et capitalism. Paris: Armand Colin.

Braudel Fernand. 1992. Kultura materialna, gospodarka i kapitalizm XV-XVIII wiek. Gry wymiany. Warszawa: Państwowy Instytut Wydawniczy.

Castells Manuel. 1972. La Question urbaine. Paris: Libraire François Maspero.

Castells Manuel. 1982. Kwestia miejska. Warszawa: Państwowe Wydawnictwo Naukowe.

Giddens Anthony. 1998. Socjologia. Poznań: Zysk i S-ka Wydawnictwo s.c.

Gravari-Barbas Marie. 2001. Les nouveaux loisirs créent-ils un nouvel urbanisme? W: Les Actes du Festival International de Géographie. http://archives-fig-st-die.cndp.fr/actes/actes_2001/ barbas/article.htm [dostęp: 2018.05.27].

Halawa Mateusz. 2015. Czasoprzestrzeń kredytu. W: Smutek konkretu. R. Drozdowski, M. Frąckowiak (red.), 185-192. Warszawa: Fundacja Bęc Zmiana.

Harvey David. 2012a. Paris, capitale de la modernité, Paris: Les Prairies Ordinaires.

Harvey David. 2012b. Bunt miast. Warszawa: Fundacja Bęc Zmiana. 
Jałowiecki Bohdan, Beniamin Kostrubiec. 1970. "Cognitive sens of J.Quinn's ecological hyphotesis". The Polish Sociological Bulletin 1: 128-134.

Jałowiecki Bohdan. 1998. Społeczne wytwarzanie przestrzeni. Warszawa: Książka i Wiedza.

Jałowiecki Bohdan. 2010. Społeczne wytwarzanie przestrzeni. Wyd. II. Warszawa: Wydawnictwo Naukowe Scholar.

Lefebvre Henri. 1972. Le droit á la ville suivi Espaces et politique. Paris: Anthropos.

Low Setha M. 2003. "Construire l'exlusion á travers les communautés fermées“. Les Annales de la Recherche Urbaine 93: 149-157.

Makowski Grzegorz. 2003. Światynia konsumpcji. Geneza i społeczne znaczenie centrum handlowego. Warszawa: Wydawnictwo „Trio”.

Merriefield Andy. 2016. Nowa kwestia miejska. Warszawa: WN Państwowe Wydawnictwo Naukowe.

Smith Neil. 1979. "Toward a theory of gentrification: A back to the city movement by capital, not people". Journal of the American Planning Association 45: 538-548.

Rifkin Jeremy. 2001. Koniec pracy. Wrocław: Wydawnictwo Dolnośląskie.

Zieliński Marcin. 2005. Luksusowe ulice: Szlaban dla matki. Gazeta Wyborcza [23.08].

\section{Źródła internetowe}

www.domy.pl [dostęp: 01.09.2017].

http://biznes.interia.pl/nieruchomosci/news/ceny-dzialek-budowlanych-w-polsce,1828732,4206 [dostęp: 01.09.2017].

http://prnews.pl/wiadomosci/ceny-wynajmu-biur-w-warszawie-luty-2016-r-3478841.html [dostęp: 01,09.2017].

http://www.bankier.pl/wiadomosc/Raport-z-rynku-mieszkan-listopad-2016-7483938.html [dostęp: 01.09.2017].

http://stat.gov.pl/obszary-tematyczne/przemysl-budownictwo-srodki-trwale/budownictwo/ budownictwo-mieszkaniowe-tablice-przegladowe-od-1991-roku,6,4.html [dostęp: 01.09.2017]. https://www.google.pl/\#q=liczba+budowanych+mieszka\%C5\%84+w+europie [dostęp: 01.09. 2017]. http://www.rp.pl/artykul/89442-Miasteczko-Wilanow-prawie-jak-wioska.html dostęp: 27.05. 2018].

\section{Bohdan Jałowiecki}

\section{CAPITALISM AND THE URBAN QUESTION}

Abstract

In the transformation of Polish cities in the last quarter of a century, ground rent has played an important role, and developers have emerged as one of the most important actors in the production of space. As a result, we are witnessing space privatization and spatial-social polarization in cities.

Keywords: accumulation, privatization, polarization 